\title{
Negative Health Effects of the International Space Station
}

ISSN: 2578-0093

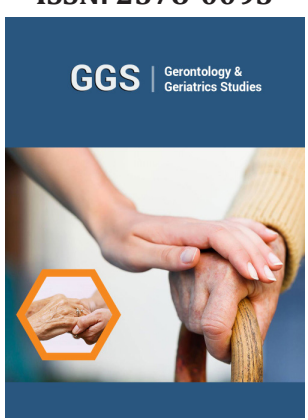

*Corresponding author: Skopec R, Researcher-Analyst, Slovakia

Submission: 海 May 27, 2019

Published: 眥August 26, 2019

Volume 4 - Issue 5

How to cite this article:Skopec R. Negative Health Effects of the International Space Station. Gerontol \& Geriatric stud.5(1). GGS.000599.2019.

DOI: 10.31031/GGS.2019.05.000601

Copyright@ Skopec R, This article is distributed under the terms of the Creative Commons Attribution 4.0 International License, which permits unrestricted use and redistribution provided that the original author and source are credited.

\section{Skopec R* \\ Researcher-analyst, Slovakia}

\begin{abstract}
The dazzling weapon was tested against volunteers firing assault weapons, sniper rifles, and machine guns at targets protected by Filin from two kilometers away. All the participants experienced difficulties aiming, and $45 \%$ had complaints of dizziness, nausea, and disorientation. Twenty percent of volunteers experienced what Russian media has characterized as hallucinations. Participants described seeing floating balls of light. But there are concerns about cloud seeding's long-term impacts. For example, it's unclear how making it rain in one village affects a neighboring village, cities, etc. It's also up for debate who "owns" the water-such as which state or company-that comes out of the clouds. There are also environmental questions, such as ones related to the long-term impacts of silver iodide. Although some critics may have concerns about companies impacting the weather with the International Space Station (ISS) that they are "playing God." One of the main causes of a Climatic Changes in our recent World are artificial interventions into Global and different Local Weather from the International Space Station regulated by Russia.
\end{abstract}

Keywords: Health effects; Weather modification; Rain making; Silver iodide; International space station; The dazzling weapons; Hallucinations; Dizziness; Nausea; Disorientation; Playing god; Temporary blindness; Blinding laser weapons

\section{Introduction}

The concept behind "dazzling" weapons has been around for decades in one form or another. Blinding weapons, particularly lasers, that because permanent blindness is prohibited by the Protocol on Blinding Laser Weapons. As Russia's weapon reportedly only causes temporary blindness, there would be no legislative restrictions on its use, not that legal issues may be of any real concern [1-3]. US-Russian relations sank to a new low, when the Trump administration announced US withdrawal from the Intermediate-range Nuclear Forces (INF) Treaty, a Cold War-era nuclear arms pact, citing Russian violations of the agreement $[4,5]$.

\section{Negative health effects of international space station}

We are living in Slovakia, and interestingly, we have also such an experience with probably new types of Psychological Weapons. It can be valid as minimum in my home district Nové Zámky, and my home place village Dubník. More than about 3 years we can observe during night (from 1900 to 0500 hours) in the sky a new object very similar to the International Space Station (ISS). I have named this suspected flying object as "Five Clouds Object" (FCO). They are not only monitoring our region but can be suspected from several attacks for using the Microwave and Sonic Beam's Weapons against oppositional politics and critical intellectuals living in our region. It seems like there can be a difference that while ISS has been constructed with rectangle geometry, above big new space object of Psychological Warfare FCO was constructed with square geometry. But it was only illusion. Another difference is that at the 4 corners of the FCO are visible 4 relatively big clouds, and the fifth, biggest cloud is in the center place of above Five Clouds Object. We have a growing number of data which are showing, that this FCO can be a Psychological Weapon of the "underworld" with help of some Foreign Power geographically situated relatively close to Slovakia, for example Russia. In our region is placed a company named AT Dunaj Dubnik, Slovakia, which has close contacts with Russian firms, and which can be also suspected from misuse of the sonic and dazzling weapons. Similarly, the company AT Dunaj Dubnik probably may have business exchange with Russian firms violating the European Union's (EU) Sanctions Regime (for example in May 15, 2019 they have sent a big TIR car to Russia, etc.), soften misusing production of artificial rain making, by which is partly destroying the Climate in the region of District Nove Zamky, Slovakia, etc. From above reasons our question is if the responsible official organs of Slovakia have some relevant 
knowledge or agreements on these dazzling weapons by using the International Space Station? [6-8].

\section{New rain-inducing techniques developed by Russian hi- tech firms}

Russia's government-back tech corporation Rostec said in 2017 that it has developed a new technique of inducing rain and planned to begin mass production of a corresponding device in the fourth quarter of 2017 [4,5]. The technique is based on the use of silver-iodide-containing substance. A cartridge charged with this substance is fired over a cloud from plane. A rain front forms within a span of 30 minutes, Rostec informed in a press release. According to the corporation, the technique was successfully tested in late July 2017 to "induce precipitation in areas swept by forest fires. Rostec collaborator under this project is Research Institute of Applied Chemistry. Now, Rostec's companies turn out several types of such products, namely Alazan anti-hail rockets, PV-26 rain inducing cartridges and Nuris anti-avalanche systems. One cloud may have up to several dozen tones of water, but rain not always falls where it is needed. Today they have learnt to control this process. In terms of practical application, this technique can be used to extinguish fires-and this is only one of the spheres where this development can be utilized. They plan to expand cooperation with Russia's Federal Aerial Forest Protection Service (Avialesoochrana) and the Federal Service for Hydrometeorology and Environmental Monitoring (Rosgidromet). Rain-inducing techniques can be also used by farming companies to irrigate drylands, said Artyom Muranov, marketing director at the Research Institute of Applied Chemistry. One of the suspected companies in Slovakia is AT Dunaj Dubník, which one may have reportedly also contacted to Military Intelligence to use above Russian techniques to negatively influence the local Weather and cause a serious disease for the inhabitants of our district of Nové Zámky, Slovakia, Central Europe.

\section{Negative effects of the dazzling weapons can cause carcinogenesis}

From the official US State Department data is known that already in the year 1978 from the 22 American diplomats working in Moscow had got 18 (!) health problems with their carcinogenesis. This situation has been only worsened further during later decades' development at the field of sonic weapons. Today there are a lot of possibilities for example to use sonic weapons from the space satellites, like is category of Russian ERA-GLONASS satellites, (they can blockade completely the whole electronic system of the terrestrial cars), etc. $[4,5]$. I was working at the embassy of the slovak republic to russia in moscow during the years 2002-2006 as the First Secretary and have also some similar problems with Sonic Attacks. In December 2017 I have sent my request to the Miroslav Lajčák's Ministry of Foreign Affairs of the Slovak Republic (MoFA SR) in Bratislava to make investigation of my case of sonic health problems. The official Human Resources' General Secretary of the MoFA SR Pavol Sýkorčin have sent me several months ago a letter rejecting my request for as minimum financial rehabilitation from suffered damage during my above diplomatic mission in abroad. It can be also understood as a shameful case of Moral Incompetence. Leaders of Foreign Ministry must take responsibility for this longlasting Moral Incompetence and Qualification Default at their MoFA of Slovakia [1-3].

We have asked the Permanent Mission of Sweden to the United Nations to introduce a new initiative on illegalization of the Sonic and Dazzling Weapons (Bio-acoustic deterrents) with formulation of a new International Treaty on Prohibition of the use of the Sonic Weapons. They must be prohibited because are causing Carcinogenesis and Death of Humans. We here in my home in Dubnik h n 317-318, Slovakia have a new tragic case when one of the neighbor living next-door Tomas Pinke and his son Sebastian Pinke reportedly were misused the Bio-acoustic deterrents against Mária Deáková (66) who had in 3 weeks got a carcinogenesis of liver and from this reason has at July 17, 2018 died !

\section{Incompetence of the traditional medicine}

The Traditional Medicine has not enough information and means to heal these new types of health disorders caused by sonic weapons. We also propose to update the International Diseases' Register of the WHO with new Diagnosis of Carcinogenesis caused by Sonic Weapons. Today there is ongoing a Secret Sonic Weapons War between big powers, and smaller countries too, first of all at the level of their Military Intelligence, which is one of the leading causes of the World Cancer Epidemic! (4) The problem is that the victims of these secret operations don't know about the dangers of carcinogenesis caused by above Secret Sonic Weapons. For this reason, I am convinced, that the topic of dazzling weapons caused carcinogenesis is also relevant for bigger interest from the circles of the United Nations and the World Health Organization and other similar international organizations.

The secret use of Sonic Weapons leading to the Carcinogenesis may become a new diagnosis of Diplomatic Disease in abroad, and means used against Oppositional Politicians, Critical Intellectuals, etc. Moreover, Sonic Weapons can be used also for the influencing of the Foreign Policy of States at the international stage. For example, the health problems of the President of the European Commission Mr. Jean-Claude Juncker during the last NATO Summit in Brussels, in July 11.-12., 2018, were probably caused by Sonic Weapons (the body imbalance, etc.). It was maybe done for clear Political Goals of the Disintegration of NATO... Similar case to the Case of Mr. J-C Juncker was happened recently to former reporter of Radio Slovensko, Bratislava: Branislav Dobšinský and was probably caused by Sonic Weapons too. I am convinced now that the use of Sonic Weapons will bring a fundamental change in Diplomacy and in the means of International Policy making [6-8].

\section{Brains of psychopats as a default-mode networks}

Regardless of whether they are characterized as compensated psychopaths, partial psychopaths, subclinical or sub criminal psychopaths, these psychopaths cause others to suffer until carcinogenesis caused by distress. Psychopaths have nonexistent conscience. Dr. Robert Hare, the world's foremost expert on the psychopaths, described psychopathy as a socially devastating 
disorder defined by a constellation of affective, interpersonal and behavioral characteristics. Particularly characteristic of the psychopath are shallow emotions, the utter absence of empathy, guilt, remorse, superficial charm, manipulativeness, inconsistency, deceitfulness and grandiose sense of self-worth. Lacking any genuine remorse, psychopaths also lack the motivation to change. It's generally thought that not only do psychopaths not get better with treatment, but they actually get worse because they learn how to better manipulate the system, as well as the clinicians who try to treat them [9-12].

\section{A system run for psychopats}

The term Antisocial Personality Disorder (ASPD) was originally meant to replace the charged and not clearly distinguishable terms psychopath and sociopath to describe psychopathy [1315]. Dr. Hare argues convincingly that ASPD and psychopathy are in reality describing different disorders. The incidence of ASPD has been estimated at 3\% in males and $1 \%$ in females, while the psychopathy is about $20 \%$ to $50 \%$ of the rate of ASPD. With 300 million people of the United States therefore has a range of 1.2 to 3 million psychopaths. There are fewer than 100 clearly dangerous serial killers, this suggests that about 1.2 to 3 million other socially dangerous psychopaths [16-18].

\section{The psychopaths are winning}

Psychiatrist H Cleckley, in his seminal work The Mask of Sanity, which first put together the characteristics of psychopaths, noted that psychopaths are apparently sane, often dynamic, almost always seductive, impress others with their sincere motives and positive intentions and wind up causing great institutional and personal harm ! These psychopaths are one of the more harming cause of the carcinogenesis caused by the distress emitted by psychopaths into their recent environment [19-21]. Charm, a quick sensitivity to the unspoken needs of others, and certain flexibility with the truth are woven into a personal charisma of psychopaths that entrances. Psychologist Robert hare, in his classic book without conscience: The Disturbing World of the Psychopaths Amon Us (1993), states: Psychopaths are social predators who charm, manipulate, and ruthlessly plow their way through life, leaving a broad trail of broken hearts, shattered expectations, and empty wallets. Completely lacking in conscience and in feeling for others, they selfishly take what they want and do as they please, violating social norms and expectations without the slightest sense of guilt or regret. If you catch him lying, he'll just shift gears and go on as though nothing had happened. Good people are rarely suspicious: they cannot imagine others doing the things they themselves are incapable of doing. Psychopaths are the monsters of real life [2225].

Robert hare said, the majority of people and therefore workplaces are easy prey, because we still want to believe that people are inherently good. We don't really want to believe that such people exist. So, I tis that Robert hare, the world's best-known expert on the psychopath, concludes that the ultimate problem is-Us! Whenever you find Money, prestige and power you will find them. The fundamental characteristic of all psychopaths is having no conscience, consequently lacking any empathy. They are in business, law, politics, and the media. They're winning by the probability coding! [1-3].

\section{The neural basis of the logarithmic mental number line in probability coding}

In the early days of neurophysiology, a few neurons that encoded number were reported in the association cortex. Nieder [9] and Miller [21] recorded in monkey prefrontal cortex the number neurons (Principal sulcus, Arcuate sulcus, 1) [10,11]. It was recording also in parietal cortex, and also in prefrontal cortex, reported the observation of neurons whose firing rate was tuned to a specific numerosity. This was possible to examine the neural code for an abstract psychological continuum $[14,15,26]$. There is often evidence that the stimulus compression occurs at a peripheral sensory level. Information is classically defined as reduction of the uncertainty, measured by the entropy function (16), which is the weighted sum of the logarithm of probability $(p)$ of alternatives outcomes (i): $H=-\Sigma p_{i} \log _{2} p_{i}$. The neural code for number can be also described in better way by logarithmic than by a linear scale. The monkeys encode the numerosity's on an approximate compressed scale confirms that this approximation is the natural way that number is encoded in a brain without language $[22,23]$.

\section{Neural coding of expected value (EV)}

Comparative theorists proposed that regions innervated by mesolimbic dopamine projections play a critical role in the computation of EV. Because fMRI studies also indicate that:

A. gain outcomes instead activate the mesial prefrontal cortex (MPFC),

B. the outcomes involve a collapse of probability,

C. increased gain probability (PRB) might increase MPFC activation, even during anticipation,

D. the ventral tegmental area midbrain dopamine neurons that project to the nucleus accumbens (NACC), and MPFC have also been implicated in the computation of $\mathrm{EV}$.

E. $[9-11,25]$

The main effect of probability coding is correlated:

1. with activation foci in the bilateral MPFC,

2. the left parahipocampal gyrus,

3. the posterior cingulate.

The interaction MAG (gain magnitude) by PRB was only correlated with activation foci in the bilateral medial caudate and right putamen [12,13].

The bilateral MPFC showed activity consistent with representation of:

a) the probability,

b) the value terms of EV. 
The bilateral anterior cingulate activation might relate to integration of these two terms:

the value and probability terms of EV. Investigation of the neural correlates of EV, mesolimbic regions (including the midbrain, NACC, and MPFC) showed activation correlated with a linear model of EV. Whereas NACC activity correlated only with anticipated MAG, MPFC activity also correlated with anticipated gain probability [27-30]. MPFC activation was associated with the perceived probability of obtaining large gains. These findings suggest, that distinct mesolimbic regions play different roles in EV computation. The MPFC showed linear but not quadratic trends, supporting probabilistic rather than uncertainty-based interpretations.

\section{Intuition probability at microscopic level misused by psychopaths}

Probabilities of the mathematical intuition (MI) at the microscopic level are mostly misused by psychopaths what are governed by interfering probability amplitudes rather than by additive probabilities. In accordance with the Bohr's correspondence principle the quantum scalar product $W_{m, n}$ between two stationary states $u_{m}$ and $v_{n}$ can be visualized as the overlap between two states depicted in $x-p$ oscillator phase space as occupied bands traversed in a clockwise direction. The total probability amplitude $W_{m, n}$ is the sum of contributions $A_{m, n}^{1 / 2} \exp \left( \pm i \varphi_{m, n}\right)$ from the two zones. Here the phase $\varphi_{m, n}$ is area between the center lines of the two states. The area-of-overlap concept illustrates the interference in phase space [4,31,32]. Interfering areas of overlap in phase space as a measure of interfering transition probability amplitudes brings us to Wigner's phase space function, which provides directly the probability $W_{m, n}=\left|W_{m, n}\right|^{2}$. The overlap between the Wigner functions ${ }^{\left.P_{m}^{(i)}\right)}$ and ${ }^{\left.P_{p}^{(i)}\right)}$ when integrated over the total phase space, yields the probability ${ }_{m, n}$

$$
W_{m, n}=2 \pi \int_{-\alpha}^{\alpha} d x \int_{-\alpha}^{\alpha} d p P_{m}^{(W)}(x, p) P_{n}^{W}(x, p)
$$

The Wigner function approach deals in terms of probabilities. Interference effects must therefore originate from phase space domains where the Wigner function product $P_{m}^{(W)} \cdot P_{n}^{(W)}$ assumes also negative values. The jump probability ${ }_{m, n}$ is the weighted overlap in phase space between the Wigner functions representing the two quantum states. The main effect of probability is negatively correlated: with activation foci in the left anterior cingulate, left insula, bilateral medial caudate, right putamen. Mathematical intuition (MI) is based on the inputs from number neurons, without Morita equivalence in circuit, mapped to the mesial prefrontal cortex (MPFC) in a process computed due the complex probability amplitudes. Intuition (I) than means mapping of number neurons to the nucleus accumbent (NACC), based on computations of added probability $[33,34]$.

\section{Dazzling weapons cause circadian disruption and cancer proliferation}

Circadian disruption has multiple pathological consequences, but the underlying mechanisms was largely unknown. To address such mechanisms, we subjected transformed cultured cells to chronic circadian desynchrony (CCD), mimicking a chronic jetlag scheme, and assayed a range of cellular functions. The results indicated a specific circadian clock-dependent increase in cell proliferation. Transcriptome analysis revealed up-regulation of G1/S phase transition genes (myelocytomatosis oncogene cellular homolog [Myc], cyclin D1/3, chromatinlicensing and DNA replication factor 1 [Cdt1]), concomitant with increased phosphorylation of the retinoblastoma (RB) protein by cyclin-dependent kinase (CDK) 4/6 and increased G1-S progression. Phospho-RB (Ser807/811) was found to oscillate in a circadian fashion and exhibit phaseshifted rhythms in circadian desynchronized cells. Consistent with circadian regulation, a CDK4/6 inhibitor approved for cancer treatment reduced growth of cultured cells and mouse tumors in a time-of-day-specific manner. Some studies identify a mechanism that underlies effects of circadian disruption on tumor growth and underscores the use of treatment timed to endogenous circadian rhythms. Circadian misalignment caused by altered sleep-wake cycles, shift work, or frequent jet lag increases susceptibility to several disorders, including cancer. However, the mechanisms by which circadian disruption contributes to disease are not well understood, and so we addressed this issue by investigating the molecular, cellular, and biochemical consequences of chronic circadian desynchronization. Studies using cancer cell or tumor tissue models show that chronic circadian desynchronization induces multiple oncogenic pathways to promote cell proliferation. In particular, chronic circadian desynchronization promotes phosphorylation of the retinoblastoma (RB) protein, thereby favoring G1/S phase cell cycle progression. Consistent with these findings, the antiproliferative activity of a selective inhibitor of the enzyme that phosphorylates RB has time-of-day-specific effects on cancer cells and mouse tumors, but this time dependence is abrogated by chronic jet-lag conditions. These data suggest a circadian regulation of G1/S cell cycle progression and provide an important molecular rationale for time-of-day-specific treatment of cancer patients, also known as chronotherapy [4,5,35].

\section{Rain maker psychopaths are 'playing god'}

Don't call them the weather gods, but this company can make it rain. North Dakota-based Weather modification International uses planes to target clouds and draw out more rain from them. The concept, called cloud seeding, has been around for decades. But there is new urgency due to climate change and a rapidly growing global population, which have disrupted global water supplies. Similarly, also Slovak company AT Dunaj Dubnik often has a behavior of The Weather Gods destroying its local environment and health of inhabitants of Dubnik, Slovakia.

By 2025, two-thirds of the world's population may face water shortages, according to the World Wildlife Fund. Weather Modification describes cloud seeding as "an enhancement" of the natural precipitation process. The technology makes storms more efficient by getting additional moisture out of clouds. To do this, pilots target clouds with lots of moisture and inject small amounts of an inert chemical, which is a silver iodide mixture. The water in the clouds condenses around the new particles and becomes heavy. Then, it falls to the ground as precipitation. The idea is that once 
we're on top of a storm, as this passes through any liquid water, it's going to freeze it and turn it to snow, so it can fall out of the cloud. Cloud seeding didn't get much attention until 2017 when the National Science Foundation funded a study to determine its effectiveness. Weather Modification, launched in 1961, provided planes for the study $[4,5]$.

The company sees cloud seeding as part of a solution for droughts. Snowpack is packed snow that melts slowly. It feeds streams and rivers as it melts. Companies are also interested. Idaho Power, which serves over 500,000 customers and has 17 hydroelectric power plants, invested more than $\$ 3$ million dollars in a cloud seeding program to boost the snowpack in Idaho's highest mountains. "That's what feeds our streams and rivers and feeds our hydro system later in the summer and fall and that's really when we need that extra energy," said Shaun Parkinson, water resource leader at Idaho Power. As a result of the cloud seeding program, it's seeing an $8 \%$ to $15 \%$ percent increase in snowpack. On average, that means it can power an extra 60,000 homes, for the company. The company has also seen a $300 \%$ return on its investment, which is equal to $\$ 9$ million dollars' worth of water that otherwise wouldn't have fallen onto mountain peaks. But Idaho Power isn't the only one to benefit, according to Weather Modification.

With cloud seeding a program such as this, it's a huge benefit to some companies, but that additional water also makes problems for the municipality, for agriculture, and more and more problems for consumption and life of inhabitants. So not everybody is benefiting. But there are concerns about cloud seeding's long-term impacts. For example, it's unclear how making it rain in one village affects a neighboring village, cities, etc. It's also up for debate who "owns" the water -- such as which state or company -- that comes out of the clouds [35]. There are also environmental questions, such as ones related to the long-term impacts of silver iodide. Although some critics may have concerns about companies impacting the weather, the company disputes that it's "playing God" $[4,5]$.

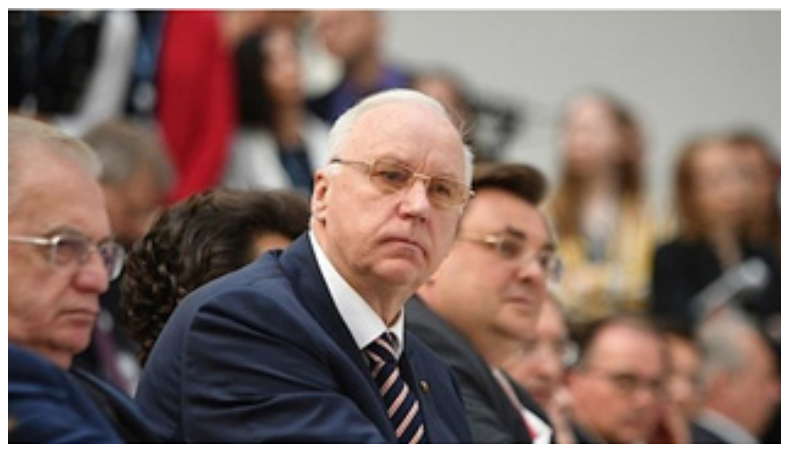

Figure 1: General alexander bastrykin, the head of russia's investigative committee (a sort of super attorney general)

Investigation at the Russian space organization: billions has been stolen "We have been working in Roskosmos for five years. Billions were stolen there. Billions. And do not see the end. The technology is simple - first exceeds the money, then the family and finally the perpetrator himself," Bastrykin said with an obvious reference to Jaskin, who fled to the west during a business trip. According to Kommersant, he was last seen in Greece. The director of the Roskosmos Institute is now being examined by FSB's secret service. The institute is one of the key companies in the rocket industry and develops satellite navigation devices that use satellite navigation (Figure 1). It also controls and resists the space base (including the ISS) and electronic devices from the space apparatus to cosmic rays. "He was obviously afraid that the scramble of budget funds would be revealed and therefore he had left the country before the investigation began" source

\section{Problem roskosmos}

Roskosmos confessed to the robbers but played down them: "The cases designated by the committee of inquiry Alexander Bastrykin is known to the public. " They are also examined and examined by the FSB.

There have been reports in the media that internal controls in Roskosmos, presumably ordered by Russian President Vladimir Putin himself, have led to the sssflaunch of 14 criminal proceedings. Steel and corruption are considered one of the main causes of failure in the Russian space program. Roskosmos chief Dmitry Rogozin has promised to place orders in the organization, TASS said. "We need to put in place, develop an economic and economic audit. Not everyone likes it, but we will go this way," says Rogozin. According to him, Roskosmos must "get rid of the error" and come to the job everyone is waiting for him [35].

\section{Conclusion}

One month ago, I have published my article in foreign scientific journal about the about the monitoring and dazzling activities of the ISS in my village Dubnik, District of Nove Zamky, Slovakia [13]. At that time ISS was realized also several beams attacks against inhabitants in this region. Approximately after 2 weeks Russian science authorities have published in the international media information, that they had lift-off the ISS at orbit about $104,5 \mathrm{~m}$ higher than it was its former high position in the space. Probably, with this operation of lifting-off they had tried to mask visibility of the ISS in our region. In this connection we can see as one reason why the U. S. President Donald Trump have many times criticized the concept of Climatic Changes only on the basis of Global Warming. The real cause of His rejection of existing popular scientific theory on Climatic Changes may be the fact, that Mr. President D. Trump may have more secret information's about realistic activities of the ISS crew personnel on the orbit [6-8]. First of all, information's about the ISS interventions into the Weather Modifications in many different regions of our World. It is clear, that these interventions of the ISS are violating the International Law, agreements and United Nations (UN) decisions. I am afraid, that if secret information's of the US President are valid, then we can see this as a Global Hybrid War (GHW) with Climatic Changes from the ISS against Human Civilization! In this case we may only condemn activities which, like AT Dunaj Dubnik, giving help to ISS crew personnel's countries with this Global Hybrid War with Climatic Changes. It may be also an interesting question, why the Western countries delegates at ISS make a secret from their cooperation with Russia on the orbit? Our 
conclusion is that the natural global warming is not the only one cause of the ongoing Climatic Changes. Another main cause in our recent world are artificial interventions into global and different local weather from the International space station regulated by Russia, helped by companies such as at Dunaj Dubnik, Slovakia. I am afraid that the ISS is the global device of a climate criminality and cannibal policy. This is another proof that in our recent world we can see, how rain maker psychopaths are causing negative health effects, while tending to achieve a psychopath's dictatorship.

\section{References}

1. Skopec R (2017) An explanation of Biblic radiation: Plasma. Journal of Psychiatry and Cognitive Behavior.

2. Skopec R (2018) Artificial hurricanes and other new weapons of mass destruction. International Journal of Scientific Research and Management 5(12): 7751-7764.

3. Skopec R (2015) Intelligent evolution, complexity and self-organization. Neuro Quantology 13(3): 299-303.

4. Kaya Y (2018) Drought woes? This tech can make it rain. CNN.

5. Yol L, Lahens NF, Zhang S, Bedont J, Field JM, et al. (2019) G1/S cell cycle regulators mediate effects of circadian dysregulation on tumor growth and provide targets for timed anticancer treatment. Plos Biology 17(4): e3000228.

6. Skopec R (2016) Translational biomedicine and dichotomous correlations of masking. Translational Biomedicine 7(1): 47.

7. Skopec R (2018) All humans are pre-programmed to innate carcinogenesis through the co-occurrence of metastases caused by quantum entanglement entropy. Archives of Oncology and Cancer Therapy 1(2): 29-36.

8. Skopec R (2019) Naphazoline nitrate treat the Frey effect of microwave and the sonic weapon's damages in human's internal, endogenous organs. Annals of Biomedical Science and Engineering 5(1): 28-38.

9. Tononi G, Edelman G (1998) Consciousness and complexity. Science 282(5395): 1846-1851.

10. Tononi G (2004) An information integration theory of consciousness. BMC Neurosci 5: 42.

11. Raichle M (1998) The neural correlates of consciousness: an analysis of cognitive skill learning. Philos Trans R Soc Lond B Biol Sci 353(1377): 1889-1901.

12. Gödel K (1947) What Is cantor's continuum problem? The American Mathematical Monthly 54(9): 515-525.

13. Fiorillo CD, Tobler PN, Schultz W (2003) Discrete coding of reward probability and uncertainty by dopamine neurons. Science 299(5614): 1898-1902.

14. Ridderinkhof KR, Wildenberg WPM (2005) Adaptive coding. Science 307(5712): 1059-1060.

15. Machens CK, Romo R, Brody CD (2005) Flexible control of mutual inhibition: A neural model of two-interval discrimination. Science 307(5712): 1121-1124.
16. Knutson B, Taylor J, Kaufman M, Peterson R, Glover G (2005) Distributed neural representation of expected value. The Journal of Neuroscience 25(19): 4806-4812.

17. Schulz W (2004) Neural coding of basic reward terms of animal learning theory, game theory, microeconomics and behavioral ecology. Current Opinion in Neurobiology 14: 139-147.

18. Bieberich E (2002) Structure in human consciousness: A fractal approach to the topology of the self-perceiving an outer world in an inner space. Medical College of Virginia Campus of Virginia Commonwealth University, Richmond, VA, USA.

19. Baars B (1997) In the theatre of consciousness. J of Consciousness Studies 4(4): 292-309.

20. Baars B (1988) Cognitive theory of consciousness. Cambridge University Press, New York, USA.

21. Nieder A, Freedman DJ, Miller EK (2002) Representation of the quantity of visual items in the primate prefrontal cortex. Science 297(5587): 1708-1711.

22. Dehaene S, Spelke E, Pinel P, Stanescu R, Tsivkin S (1999) Sources of mathematical thinking: Behavioral and brain-imaging evidence. Science 284(5416): 970-974.

23. Dehaene S (2003) The neural basis of the Weber-Fechner Law: A logarithmic mental number line. Trends Cogn Sci 7(4): 145-147.

24. Dehaene S, Kerszberg M, Changeux JP (1998) A neuronal model of a global workspace in effortful cognitive tasks. PNAS 95(24): 1452914534.

25. Dermott J (2002) Brain models: The next generation. Nature Neuroscience 5(9).

26. Brown JW, Braver TS (2005) Learned predictions of error likelihood in the anterior cingulate cortex. Science 307(5712): 1118-1121.

27. Mikhailovsky GE (2000) Biological time, its organization, hierarchy and representation by complex values. E Reports, Moscow, Russia.

28. Kobozev N (1971) Investigations in the field of thermodynamics and thinking processes. Moscow, Russia.

29. Wheeler J, Dowlwg JP, Schlei WP (1991) Interference in phase space. Annalen Der Physik 7: 423-502.

30. Dehaene S, Changeux JP (2005) Ongoing spontaneous activity controls access to consciousness: A neuronal model for inatentional blindness. PLOS Biology 3(5): e141.

31. Luu P, Posner MI (2003) Anterior cingulate cortex regulation of sympathetic activity. Brain 126(10): 2119-2120.

32. Carter CS, Braver TS, Barch DM, Botvinick MM, Noll D (1998) Anterior cingulate cortex, error detection, and the online monitoring of performance. Science 280(5364): 747-749.

33. Wigner E (1983) Quantum optics, experimental gravitation, and the measurement theory. In: Meystre P, Scully N (Eds.), Physics, Plenum, New York, USA.

34. Prigogine I (1997) The end of certainty: time, chaos and the new laws of nature. Centre for Digital Philosophy, New York, USA.

35. Investigation at the Russian space organization: billion has been stolen. 